\title{
The Impacts of Sea Level Rise on Basrah City, Iraq
}

\author{
Nahlah Abbas' ${ }^{1}$, Sultana Nasrin ${ }^{2}$, Nadhir Al-Ansari' ${ }^{3}$, Sabah H. Ali ${ }^{4}$ \\ ${ }^{1}$ Central Queensland University, Melbourne, Australia \\ ${ }^{2}$ RMIT, Melbourne, Australia \\ ${ }^{3}$ Lulea University of Technology, Lulea, Sweden \\ ${ }^{4}$ Remote Sensing Center, University of Mosul, Mosul, Iraq \\ Email: n.abbas@cqu.edu.au, Nasrin.Sultana@whittlesea.vic.gov.au,nadhir.alansari@ltu.se, sabah1960928@gmail.com
}

How to cite this paper: Abbas, N., Nasrin, S., Al-Ansari, N. and Ali, S.H. (2020) The Impacts of Sea Level Rise on Basrah City, Iraq. Open Journal of Geology, 10, 1189-1197. https://doi.org/10.4236/ojg.2020.1012058

Received: November 26, 2020

Accepted: December 14, 2020

Published: December 17, 2020

Copyright (c) 2020 by author(s) and Scientific Research Publishing Inc. This work is licensed under the Creative Commons Attribution International License (CC BY 4.0).

http://creativecommons.org/licenses/by/4.0/ (c) (i) Open Access

\begin{abstract}
Sea Level Rise (SLR) above the Mean Sea Level (MSL) is more likely to cause a significant risk to the coastal regions. This research explores the potential impact of sea level rise, due to climate change, on coastal areas. It examines the impact of sea level rise on Basrah city and adjacent cities in Iraq. A digital elevation model (DEM) was used to create a model of Potentially Inundated Areas, manipulated and processed in Geographical Information System version 10.7 (ArcGIS 10.7). Through this model, the impact of sea level rise was assessed on the surface area. After the susceptible areas were delineated, it was estimated that at worst case scenario of $5 \mathrm{~m}$ sea level rise will impact Basrah city by losing 38 percent of its total surface area.
\end{abstract}

\section{Keywords}

Climate Change, Sea Level Rise, Arab Gulf, Iraq

\section{Introduction}

Climate change occurs naturally, but during the last century global warming has been so rapid that it cannot be attributed to natural causes alone [1] [2]. It is now believed that anthropogenic activities such as burning of fossil fuel and land cover conversion (e.g., deforestation) have led to increase in greenhouse gases: elevated $\mathrm{CO}_{2}$ concentrations and other greenhouse gases (e.g., $\mathrm{CH}_{4}, \mathrm{~N}_{2} \mathrm{O}$, etc.) have the potential, by modifying radiative forcing, to cause global warming, which is assumed to have started since the industrial revolution of the 1850s. Many studies indicate that global warming is highly likely to cause climate shifts such as sea level rise [3]. 
Globally, mean sea level has increased by $200 \mathrm{~mm}$ since the late 19th century at a rate of $2.8 \mathrm{~mm} /$ year. Rising sea levels have accelerated to $3.2 \mathrm{~mm}$ /year over the last three decades [4] at a rate near to the upper end of the Intergovernmental Panel on Climate Change projections [5]. This is mostly due to thermal expansion of the oceans, with a small contribution from the loss of mass from land ice [6]. The increase in the sea level due to climate change is more likely to impact many coastal areas and inundate low-lying regions. In addition, modelled and observed studies show that due to the rise in sea level and an increase in global temperatures, the coastal regions will experience more storm surges in the form of hurricanes and cyclones. Considering world's human populations, infrastructure, and economic activities are concentrated along coastlines; these are significantly vulnerable to any significant change in sea levels. Many studies have been done to investigate the sea level rise and its impacts on the coastal areas and the infrastructure within these areas. Such studies are of importance to support decision makers in planning relevant adaptation and mitigation measures, and thus decreasing the adverse impacts of climate change on sea level rise.

In recent years, GIS has been used to assess the impacts of climate change on sea level rise and it has demonstrated great potential in its application and problem-solving capabilities in many diverse sectors such as agriculture, environment, water resources, natural resources, and natural hazards including flooding, drought bushfire and landslides [7]. As a result, GIS is an essential and effective way for simulating different hazard scenarios related to sea level rise. Through these scenarios, preventive measures can be taken by the authorities to avoid human and infrastructural loss. Although many research has been done using GIS to study sea level rise impacts on several sectors such as community, economy, environment in different places worldwide, no study has been done to investigate these impacts on coastal area within Iraqi boundary. Therefore, this research aims at the investigation of the impacts of sea level rise on Basrah city in particular and adjacent cities such as DhiQar and Maysan.

\section{Case Study of City of Basrah, Iraq}

\subsection{Location}

The study area of this research is Basrah Governorate with their seven districts. It's located between two latitudes of (29.05 - 31.20) north and two longitude of (46.40 - 48.40) east in the southeast of Iraq, bordered by Iran to the east and Kuwait and the Arabian Gulf from the south and southeast and Missan province to the north and the provinces of DhiQar and Muthanna from the west, Figure 1. The total area is about $\left(19070 \mathrm{~km}^{2}\right)$ with a population of (1.5 million) according to estimates of 2014. Basrah among the cities in the Arab world that face high threat of inundation, It has been revealed as one of the most populated urban areas in the Middle East vulnerable to rising sea levels, any settlement or population centre on low-lying coasts is vulnerable [8].

It is the main source of revenues for Iraq as it comprises the largest oil fields 


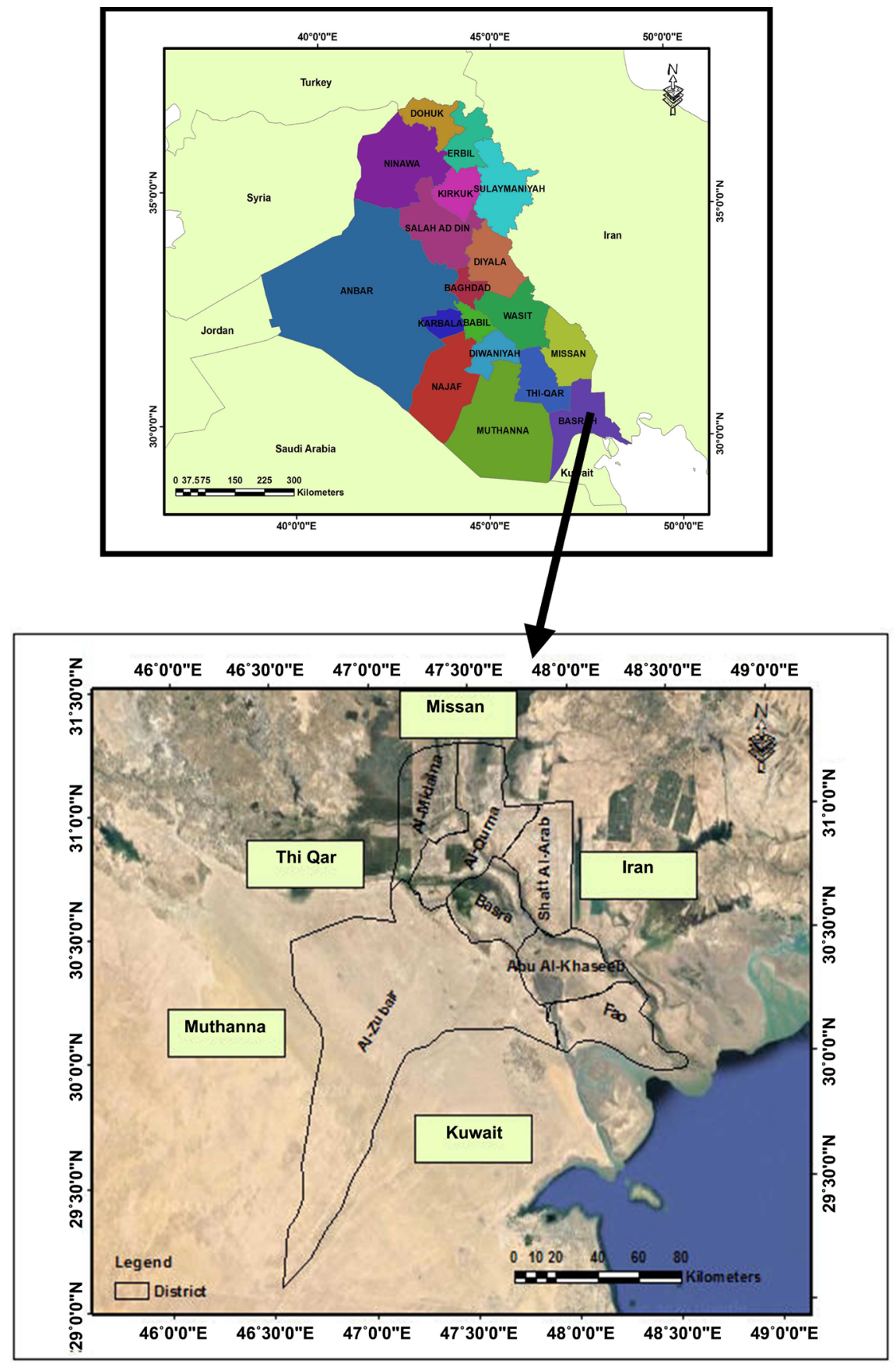

Figure 1. Boundaries of the study area.

in the country. Additionally, Basrah is Iraq's main port, so shipping, logistics and transport are also major industries in Basrah. Also, it is in a fertile agricultural region, with major products including rice, maize corn, barley, pearl millet, wheat dates and livestock.

\subsection{Topography}

Basra Governorate is part of the alluvial plain area, which is characterized by its complete simplicity in most parts of the northern and eastern governorate, while 
in the western and southwestern sections, some valleys and hills appear, represented by Tal Sanam, Figure 2. Tigris River and Euphrates merged in Qurna suburb. The combined stream is referred to as the Shatt al-Arab. The southern part of the river constitutes the border between Iraq and Iran down to the mouth of the river as it is debouching into the Arab Gulf. Basrah is low-lying floodplains and deltas where the shatt al-arab enters the Gulf with the height of 5 $\mathrm{m}$ above mean sea level and roughly $110 \mathrm{~km}$ from the Gulf.

\subsection{Climate}

Basrah experiences a warm desert climate, nevertheless, due to its location in the vicinity of the Gulf precipitation figures in Basrah are higher than it would be expected. The average air temperatures range from $11^{\circ} \mathrm{C}$ to $35.5^{\circ} \mathrm{C}$. During the summer months, from June to August, Basrah is consistently one of the hottest cities on the planet, with temperatures regularly exceeding $50^{\circ} \mathrm{C}$ in July and $\mathrm{Au}$ gust. In winter, Basrah experiences mild weather with average high temperatures around $20^{\circ} \mathrm{C}$. On some winter nights, minimum temperatures are below $0^{\circ} \mathrm{C}$. High humidity, sometimes exceeding $90 \%$, is common due to the proximity to the marshy Gulf. Rainfall in Basrah is approximately $100 \mathrm{~mm}$ per year, which is typical of a desert climate [8].

\section{Methods and Data}

GIS geoprocessing approaches were used to highlight and analyze the impact of SLR on Basrah city and assess the vulnerability of the coastal areas. This research classifies vulnerable sectors, regions, and resources and assesses the degree of

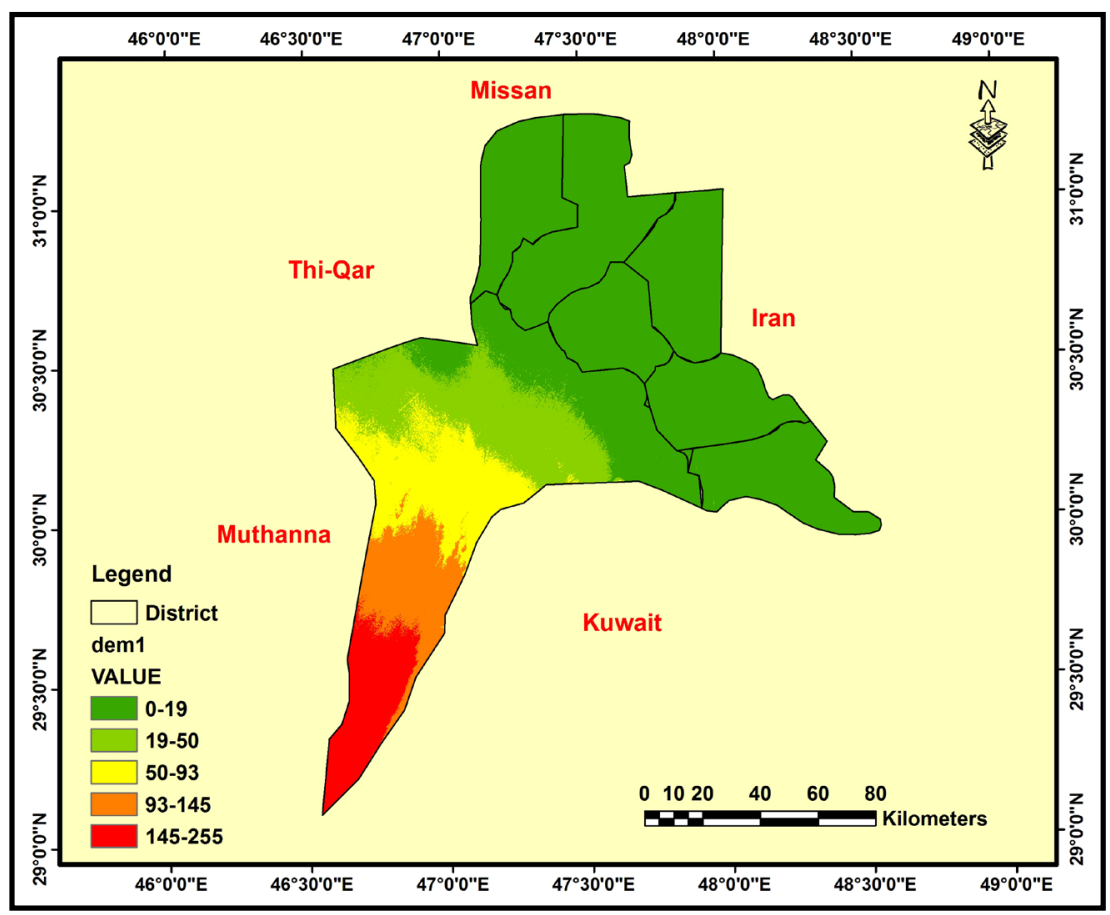

Figure 2. The elevation range of the study area. 
future risk caused by SLR to improve the city's capability to tackle the potential of increased sea level rise. The methodological framework applied in the study can be divided into two sections; first, using spatial analysis to identify the vulnerable areas to SLR, Secondly, the impacts were simulated and the results were presented in the form of simulation. The spatial analyses were conducted using ArcGIS while the simulation was generated using Google Earth program [7].

The methodological workflow applied to create the potential inundated areas and to generate spatial results is shown in Figure 3.

The DEM provided by Geoearth explorer processed and classified using GIS. Next, using the Map Algebra Expressions in raster calculator, desired cells were extracted in the form of new rasters. These new rasters were generated using the elevation values of one to five $\mathrm{m}$. These newly extracted rasters were crucial to generate the inundated areas. The generated rasters consist of cells with two values, 0 and 1.1 represented the cells that were of interest while 0 represented

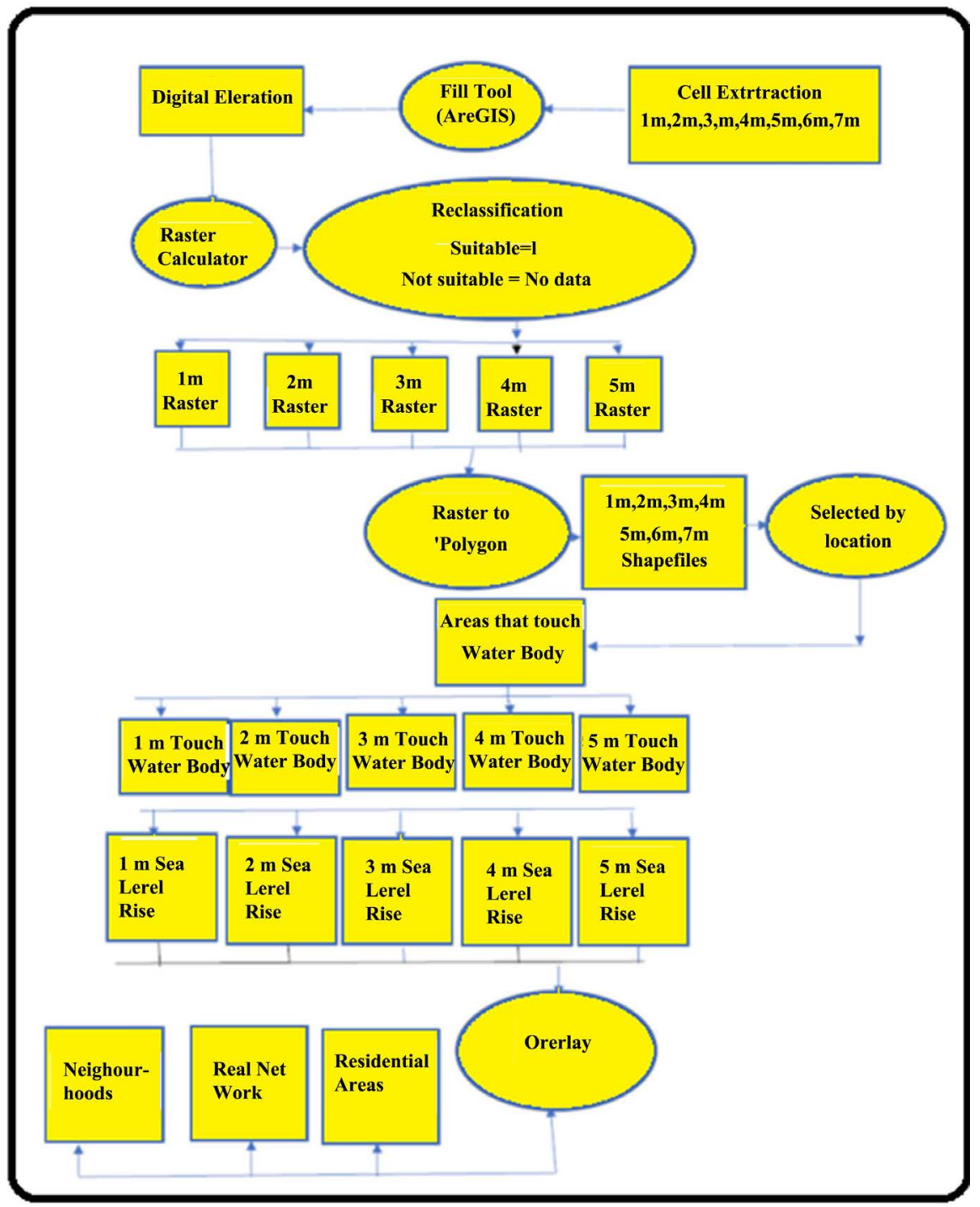

Figure 3. Method work flow chart [7]. 
the remaining cells in the raster. Therefore, these rasters were then reclassified using the reclassification tool to reclassify the 0 value cells as No Data and thus the respective cells had null values. This process was repeated for all seven rasters.

\section{Discussion}

Sea Level Rise (SLR) above the Mean Sea Level (MSL) may cause a significant hazard to Basrahh's coastal areas because of its low-lying floodplains. The hazard may extend further to the adjacent cities to Basrahh; DhiQar and Maysan. Critical infrastructures such as major ports, roads, paths, and many socioeconomic activities are clustered in the coastal areas. These areas support various economic activities including ports, airport, hotels, and industrial and commercial compounds. In addition, considerable numbers of suburbs are also clustered along the coastal areas. An increase in the sea level, not only the areas along the coast will be affected but also the low-lying adjacent land will also be inundated.

$1 \mathrm{M}$ sea level rise (as shown in blue color) is likely to affect most of the eastern part of the Iraqi coast. The river banks of Shatt al-Arab watercourse and the lands adjacent to Shatt al-Arab may be submerged. The affected area under $1 \mathrm{M}$ sea level rise would be $944 \mathrm{~km}^{2}$ (5\% of total Bsrah' area). As has been mentioned earlier, Al-Nasiriyah and Maysan cities would be affected due to their low-lying topography, as the inundated area would be $271 \mathrm{~km}^{2}$ and $328 \mathrm{~km}^{2}$ for Al-DhiQar and Maysan, respectively, (Table 1, Figure 4).

Table 1. The impacts of SLR on Basrahh, Al-Nasiriyah and Maysan under five scenarios, $1,2,3,4,5$ M SLR.

\begin{tabular}{ccccccc}
\hline Cities & $\begin{array}{c}\text { Total area } \\
\text { KM }^{2}\end{array}$ & $\begin{array}{c}\text { Inundated } \\
\text { area under 1 } \\
\text { M SLR }\end{array}$ & $\begin{array}{c}\text { Inundated } \\
\text { area under 2 } \\
\text { M SLR }\end{array}$ & $\begin{array}{c}\text { Inundated } \\
\text { area under 3 } \\
\text { M SLR }\end{array}$ & $\begin{array}{c}\text { Inundated } \\
\text { area under 4 } \\
\text { M SLR }\end{array}$ & $\begin{array}{c}\text { Inundated } \\
\text { area under 5 } \\
\text { M SLR }\end{array}$ \\
\hline Basrahh & 19,070 & 944 & 2379 & 4124 & 6486 & 7379 \\
Al-Nasiriyah & 12,900 & 271 & 1235 & 2350 & 2980 & 4676 \\
Maysan & 16,072 & 328 & 460 & 1215 & 1861 & 2632 \\
\hline
\end{tabular}

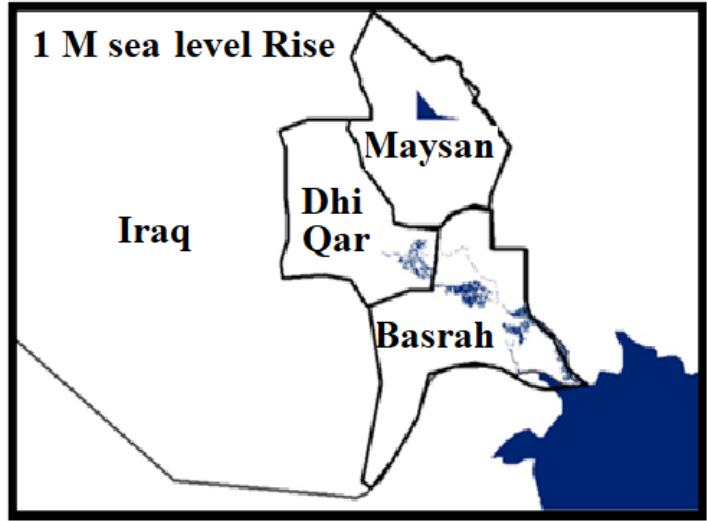

Figure 4. 1 M SLR impacts on Bsrah, DhiQar and Maysan. 
Under $2 \mathrm{M}$ sea level rise scenario, in Basrah the inundated area would be more than double (2379 $\mathrm{km}^{2}$ which represents $12 \%$ of total area) compared to $1 \mathrm{M}$ sea level rise impacts. In Al-Nasiriyah, about $1235 \mathrm{~km}^{2}$ would be submerged (6 times more than in $1 \mathrm{~m}$ sea level rise scenario), while in Maysan the affected area would increase to $460 \mathrm{~km}^{2}$ (Table 1, Figure 5).

Under sea level rise 3 and 4 scenarios, Basrah would see an increase in inundated area up to $4124 \mathrm{~km}^{2}$ (21\% of total area) and $6486 \mathrm{~km}^{2}$ (32\% of total area), respectively. Al-Nasiriyah city would experience $2350 \mathrm{~km}^{2}$ and $2980 \mathrm{~km}^{2}$ of inundated area for $3 \mathrm{M}$ and $4 \mathrm{M}$ sea level rise scenarios, respectively. Maysan city, however will see an increase in submerged area up to $1215 \mathrm{~km}^{2}$ and $1861 \mathrm{~km}^{2}$ under $3 \mathrm{M}$ and $4 \mathrm{M}$ sea level rise scenarios, respectively (Figure 6 and Figure 7).

For the highest scenario of sea level rise $(5 \mathrm{M})$, the affected area in Basrah would be $7379 \mathrm{~km}^{2}$ (38\% of the total area). For Al-Nasiriyah and Maysan, the submerged area would be $4676 \mathrm{~km}^{2}$ and $2632 \mathrm{~km}^{2}$, respectively, (Figure 8).

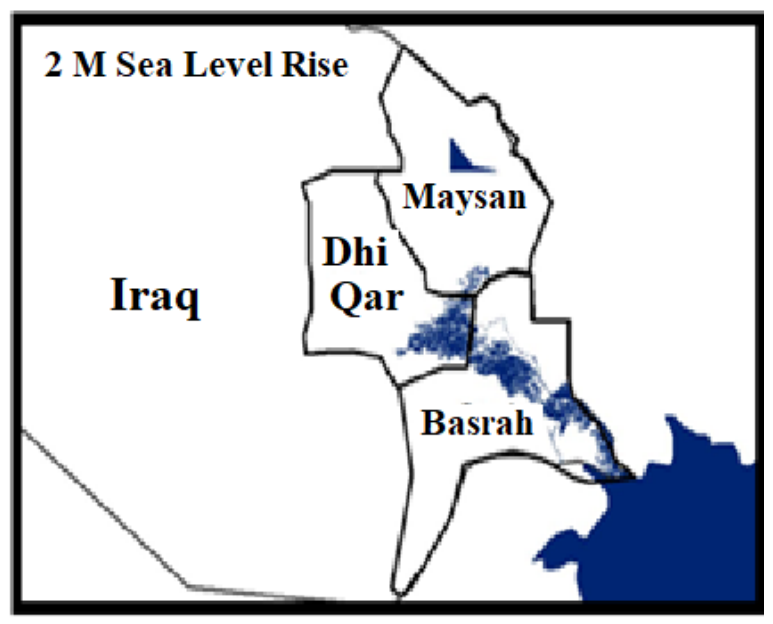

Figure 5. 2 M SLR impacts on Bsrah, DhiQar and Maysan.

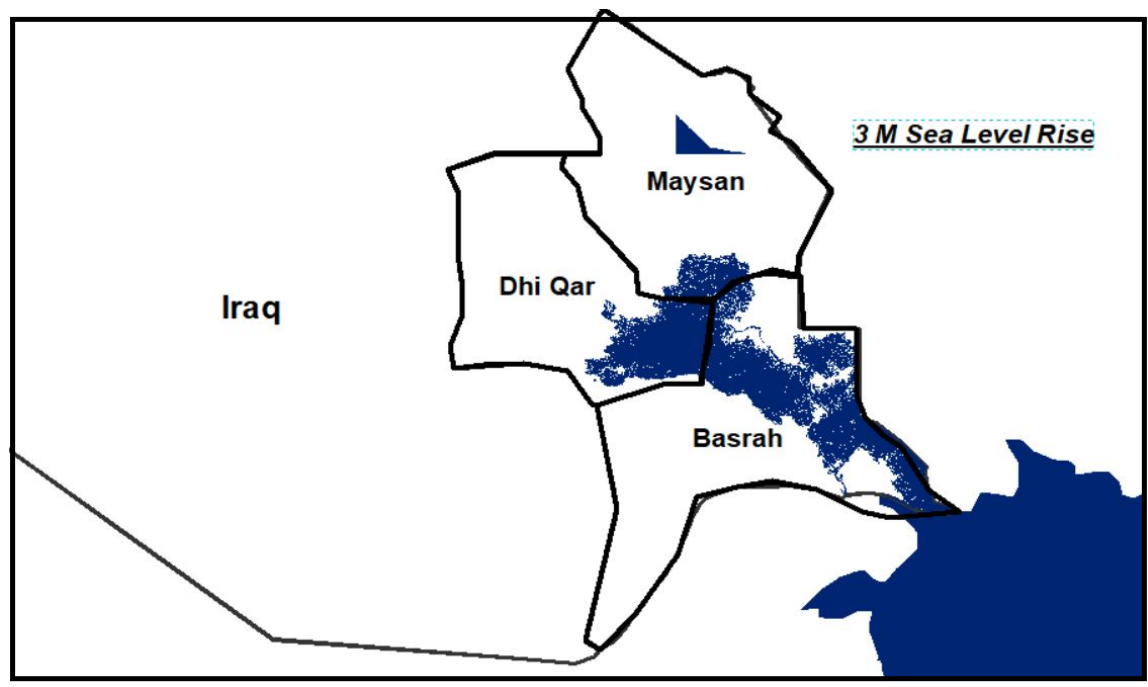

Figure 6. 3 M SLR impacts on Bsrah, DhiQar and Maysan. 


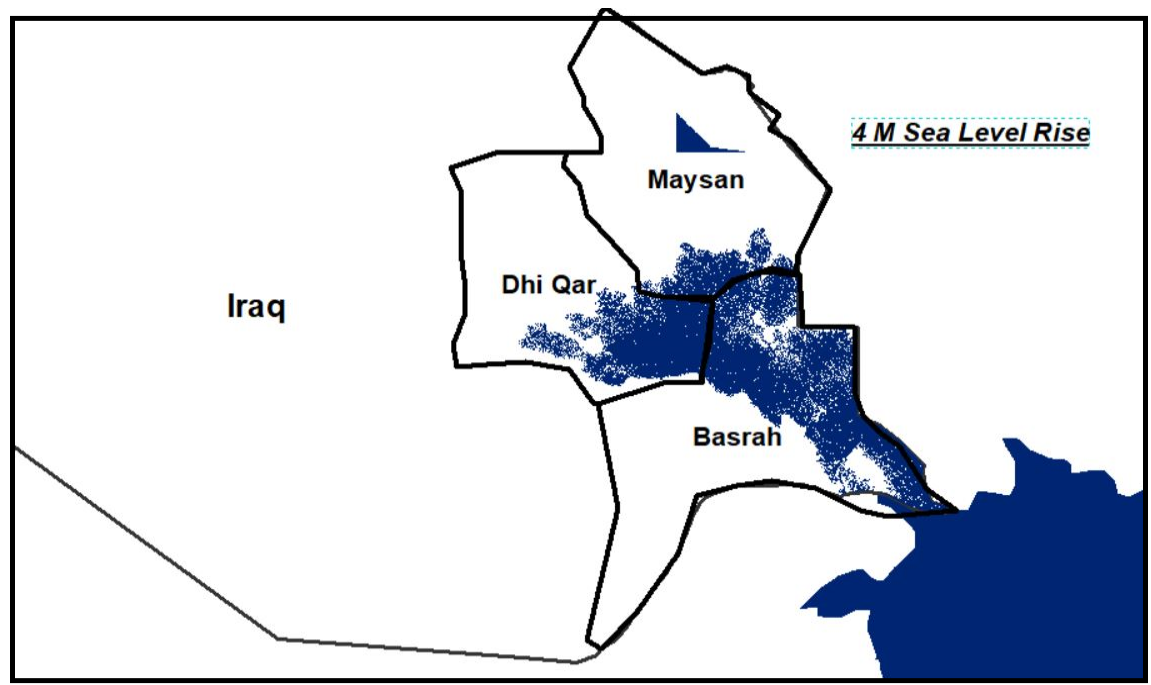

Figure 7. 4 M SLR impacts on Bsrah, DhiQar and Maysan.

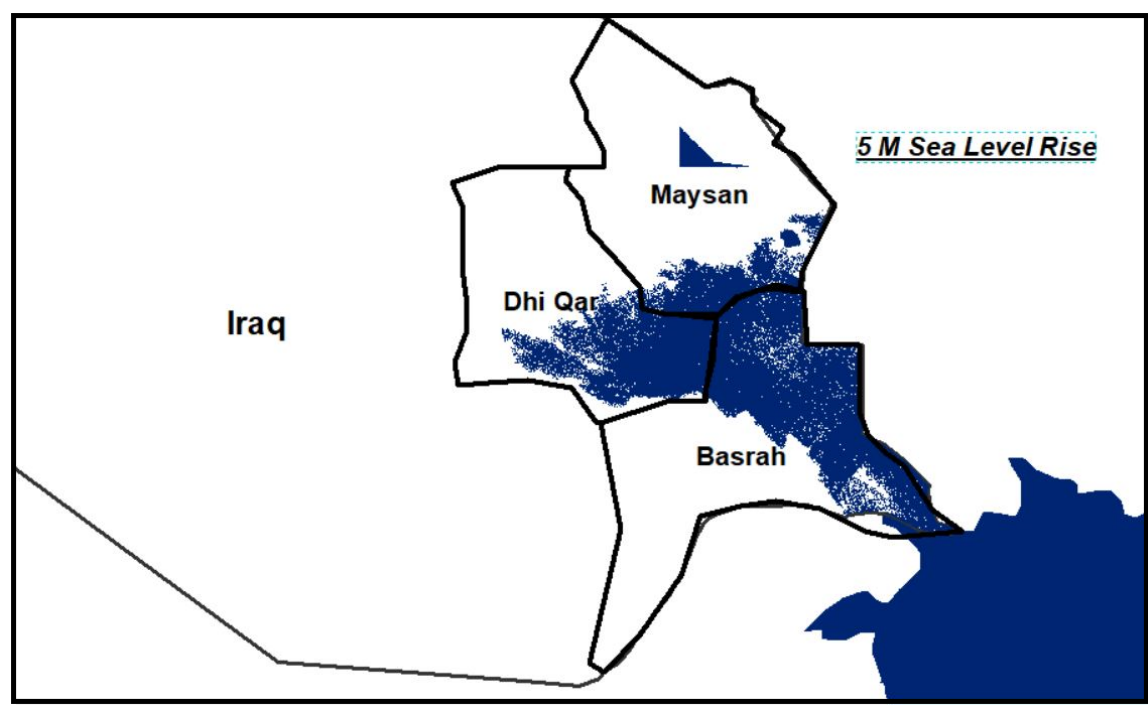

Figure 8. 5 M SLR impacts on Bsrah, DhiQar and Maysan.

\section{Conclusion}

Sea Level Rise has serious impacts on coastal area in Iraq in particular and low laying area. The sea level rise impacts on the coastal city of Basrah, the largest second city, and the adjacent cities, DhiQar and Matsan in Iraq were investigated. The results show that, in the worst scenario, $5 \mathrm{M} \mathrm{SLR}, 38 \%$ of Basrah city area would experience inundation. 36\% of DhiQar city area and 16\% of Maysan city area would be submerged. Actions need to be taken by the authorities to avoid these extreme impacts on these areas.

\section{Conflicts of Interest}

The authors declare no conflicts of interest regarding the publication of this paper. 


\section{References}

[1] Ammann, C.M., Joos, F., Schimel, D.S., Otto-Bliesner, B.L. and Tomas, R.A. (2007) Solar Influence on Climate during the Past Millennium: Results from Transient Simulations with the NCAR Climate System Model. Proceedings of the National Academy of Sciences of the United States of America, 104, 3713-3718. https://doi.org/10.1073/pnas.0605064103

[2] IPCC Climate Change 2014 (2014) The Physical Science Basis: Contribution of Working Group I to the Fifth Assessment Report of the Intergovernmental Panel on Climate Change. Cambridge University Press, Cambridge.

[3] Wu, K. and Johnston, C.A. (2007) Hydrologic Response to Climatic Variability in a Great Lakes Watershed: A Case Study with the SWAT Model. Journal of Hydrology, 337, 187-199. https://doi.org/10.1016/j.jhydrol.2007.01.030

[4] Lough, J.M. and Hobday, A. (2011) Observed Climate Change in Australian Marine and Freshwater Environments. Marine and Freshwater Research, 62, 984-999. https://doi.org/10.1071/MF10272

[5] Keenan, T. and Cleugh, H. (2011) Climate Science Update: A Report to the 2011 Garnaut Review. Centre for Australian Weather and Climate Research, Canberra.

[6] Church, J.A., Hunter, J.R., McInnes, K.L. and White, N.J. (2006) Sea-Level Rise around the Australian Coastline and the Changing Frequency of Extreme Sea-Level Events. Australian Meteorological Magazine, 55, 253-260.

[7] Malik, A. and Abdalla, R. (2016) Geospatial Modeling of the Impact of Sea Level Rise on Coastal Communities: Application of Richmond, British Columbia, Canada. Modeling Earth Systems and Environment, 2, 146. https://doi.org/10.1007/s40808-016-0199-2

[8] El Raey, M. (2010) Impact of Sea Level Rise on the Arab Region. University of Alexandria. Arab Academy of Science, Technology, and Maritime. 